\title{
Advances in Genetics and Molecular Breeding of Broccoli
}

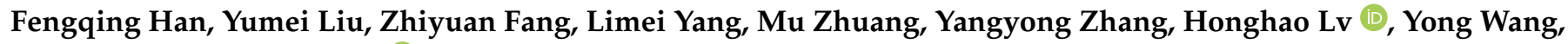 \\ Jialei Ji and Zhansheng $\mathrm{Li}$ *(1)
}

Key Laboratory of Biology and Genetic Improvement of Horticultural Crops, Institute of Vegetables and Flowers, Chinese Academy of Agricultural Sciences, Ministry of Agriculture, \#12 Zhong Guan Cun Nandajie Street, Beijing 100081, China; hanfengqing@caas.cn (F.H.); liuyumei@caas.cn (Y.L.); fangzhiyuan@caas.cn (Z.F.); yanglimei@caas.cn (L.Y.); zhuangmu@caas.cn (M.Z.); zhangyangyong@caas.cn (Y.Z.); lvhonghao@caas.cn (H.L.); wangyong03@caas.cn (Y.W.); jijialei@caas.cn (J.J.)

* Correspondence: lizhansheng@caas.cn; Tel.: +86-010-62135629

check for updates

Citation: Han, F.; Liu, Y.; Fang, Z.; Yang, L.; Zhuang, M.; Zhang, Y.; Lv, H.; Wang, Y.; Ji, J.; Li, Z. Advances in Genetics and Molecular Breeding of Broccoli. Horticulturae 2021, 7, 280. https://doi.org/10.3390/

horticulturae7090280

Academic Editor: Yuyang Zhang

Received: 6 August 2021

Accepted: 1 September 2021

Published: 3 September 2021

Publisher's Note: MDPI stays neutral with regard to jurisdictional claims in published maps and institutional affiliations.

Copyright: (c) 2021 by the authors. Licensee MDPI, Basel, Switzerland. This article is an open access article distributed under the terms and conditions of the Creative Commons Attribution (CC BY) license (https:// creativecommons.org/licenses/by/ $4.0 /)$.
Abstract: Broccoli (Brassica oleracea L. var. italica) is one of the most important vegetable crops cultivated worldwide. The market demand for broccoli is still increasing due to its richness in vitamins, anthocyanins, mineral substances, fiber, secondary metabolites and other nutrients. The famous secondary metabolites, glucosinolates, sulforaphane and selenium have protective effects against cancer. Significant progress has been made in fine-mapping and cloning genes that are responsible for important traits; this progress provides a foundation for marker-assisted selection (MAS) in broccoli breeding. Genetic engineering by the well-developed Agrobacterium tumefaciens-mediated transformation in broccoli has contributed to the improvement of quality; postharvest life; glucosinolate and sulforaphane content; and resistance to insects, pathogens and abiotic stresses. Here, we review recent progress in the genetics and molecular breeding of broccoli. Future perspectives for improving broccoli are also briefly discussed.

Keywords: broccoli; progress; genetic researches; molecular breeding

\section{Introduction}

Broccoli (Brassica oleracea L. var. italica) is a member of the Brassicaceae family and is widely cultivated as an important vegetable crop worldwide [1,2]. It produces edible hypertrophic reproductive organs (floral head and stalk), with rich health benefits and nutritious properties, such as vitamin A, vitamin K, calcium, magnesium and anticancer bioactive compounds, including glucosinolates, sulforaphane, selenium and flavonoids [3-5].

The italica group arises from the cultivation and domestication of Brassica oleracea (CC genome; $2 \mathrm{n}=18$ ) in the Mediterranean region. Accurate knowledge about the cultivation of B. oleracea mustard plants can be traced to the Hellenic culture, starting in approximately the 6th century BC [6]. By distinguishing the B. oleracea cultivars, 'Broccoli' is probably a colloquial Latin word for any projecting shoots of the cabbage family [6]. Broccoli-like varieties were developed from selections of desirable B. oleracea types during the past 2000 years and formed various broccoli landraces mainly in Italy [6-9]. The broccoli variety 'Vrocculi o Sparaceddi' is considered the first domesticated form of wild brassica from which broccoli originated [10]. During the past 300 years, the heading broccoli has greatly improved, largely attributed to selection by Danish and English horticulturists [6]. For a long time, the consumption of broccoli as a vegetable was confined to the Italian peninsula and it was grown mainly as sprouting broccoli cultivars [10]. With the breeding and improvement of calabrese broccoli varieties, a particular type producing large and compact heads more similar to cauliflower, broccoli spread and gained popularity worldwide $[10,11]$. Various broccoli landraces were introduced to the United Kingdom in the 1700s and to the United States in the 1800s and became popular after World War II [11]. Broccoli was initially introduced into several southern provinces of China in the 1980s and has been a popular vegetable widely grown in China. In recent years, China, with a cultivation area 
of over 80,000 ha, has become the largest producer of broccoli in the world [12]. Driven by scientific evidence that broccoli is beneficial to human health, the market demand is still increasing in the main broccoli-producing countries, including China, the US and India [12-14].

With the development of molecular biology technology and functional genomics, a large number of studies on broccoli have been performed. Marker-assisted selection (MAS) and genetic transformation were combined with conventional breeding to improve broccoli for high yield, quality, resistance to biotic and abiotic stresses, etc. We review the recent progress on the genetics and molecular breeding of broccoli, focusing on desirable agronomic traits, male sterility, abiotic stress resistance, disease resistance, secondary metabolites and genetic transformation. Postharvest yellowing (or prolonging shelf life) of broccoli is also a research hotspot that has been reviewed recently and thus is not included in this review [2]. Broccoli improvement by genetic engineering was reviewed in 2016 [1], so relevant advances in recent years from 2016 to 2021 are included in this review.

\section{Genetics and Molecular Breeding of Broccoli}

\subsection{Abiotic Stress Resistance}

\subsubsection{Heat Stress}

Broccoli production faces challenges of demand to extend plant areas and maintain production security under extreme weather brought by climate change $[13,15]$. Broccoli is suitable for growth in cool weather with optimal temperatures ranging from 15 to $23{ }^{\circ} \mathrm{C}$ during the early stages of floral development [16]. High temperatures above 25 severely reduce broccoli quality because (1) most broccoli germplasms require vernalization at temperatures below $23{ }^{\circ} \mathrm{C}$ and superoptimal temperatures would even result in no head formation; (2) some broccoli germplasms do not require vernalization, but floral development under high temperatures (e.g., above $30^{\circ} \mathrm{C}$ ) results in undesirable traits, such as bracting, uneven head surface and sizes of buds, discoloration or even brown bead, making the broccoli products unmarketable; and (3) high temperatures during the head maturity stage decrease broccoli yield $[15,17,18]$. In recent years, substantial progress has been made in creating heat-tolerant breeding lines and genetically controlling heat tolerance in broccoli. In the USA, researchers have made efforts to achieve sustainable broccoli production under heat tolerance in the main production area on the east coast, supported by projects (National Institute of Food and Agriculture (NIFA) Project No. 2010-51181-21062 and the USDA Vegetable Brassica Research Project (CRIS No. 6080-21000019-00D)) $[16,19,20]$. In Asia, researchers are trying to introduce broccoli to subtropical and tropical regions, such as in Taiwan, China and Indonesia [21,22].

The ability to produce high-quality heads by several broccoli germplasms under heat stress is considered a quantitative trait controlling multiple positive loci [13,15]. Lin et al. identified 31 QTLs for head size and weight phenotypes of broccoli grown in hightemperature seasons (average $36.4{ }^{\circ} \mathrm{C}$ day $/ 25.9{ }^{\circ} \mathrm{C}$ ) [23]. Branham et al. constructed a high-density genetic map by genotyping-by-sequencing of a $\mathrm{DH}$ broccoli segregating population for heat tolerance and identified five QTLs and one positive epistatic interaction between QHT_C03 and QHT_C05, explaining 62.1\% of phenotypic variation [15]. Using a new DH population of broccoli, Branham et al. performed whole-genome resequencing of bulked segregants and identified two novel heat tolerance QTLs, of which QHT_C09.2 may explain the negative correlation between maturity and heat tolerance [13].

Using reversed genetic approaches, a heat-stress-related broccoli catalase gene was cloned, and ectopic expression of this gene in Arabidopsis can enhance heat tolerance, but whether it plays a role in maintaining a high-quality head under high temperatures is still unknown [24,25]. In addition, benefiting from improved sequencing techniques and the release of reference genomes, some researchers performed omics-related studies and identified differentially expressed microRNAs/genes and potential pathways involved in heat tolerance [26,27]. 


\subsubsection{Other Abiotic Stresses}

Several studies have focused on broccoli resistance to other stresses, such as proteomic analysis for waterlogging stresses [28], microRNA analysis for salt stress [29] and transcriptome and metabolomics for wounding stress [30]; differentially expressed proteins/microRNAs/genes were identified as possibly related to resistance to these stresses [28-30].

In addition, cuticular waxes on the plant surface contribute to resistance to many environmental stresses, such as drought, UV light, high radiation and both bacterial and fungal pathogens [31]. Some loci and linked markers for this trait have been obtained. Using a natural glossy (cuticular wax defective) mutant, Branham and Farnham identified three candidates, Bo3g001070, Bo3g122030 and Bo3g008780, for this trait on C03 [32]. In the broccoli $\times$ Chinese kale-derived BolTBDH population, leaf color was segregated, which resulted from the differences in cuticular waxes between broccoli and Chinese kale; a locus for this trait, LC_C09@15.1, was identified on C09, explaining 45.64\% of the phenotypic variation [33].

\subsection{Desirable Agronomic Traits}

\subsubsection{Heading}

Broccoli produces edible reproductive organs characterized by proliferation and developmental arrest of floral buds [17]. Floral head quality is the most important agronomic trait selected by breeders. With forward and reversed genetic approaches, some genes/loci related to head formation have been identified, but the genetic basis remains elusive [34].

Some works tried to identify homologs of the Arabidopsis floral meristem identity genes LEAFY (LFY), APETALA1 (AP1) and CAULIFLOWER (CAL) and implied that BoCAL and $B o A P 1$ are involved in curding in cauliflower, a subspecies similar to broccoli but different in the developmental stage of the reproductive meristem at harvest [35-37]. Subsequent studies suggest that heading is quite complex in both cauliflower and broccoli, which seems not to be controlled solely by these floral genes [34].

In the 1990s, researchers started to construct genetic maps by crossing broccoli cultivars/inbred lines with various materials, including broccoli cultivar/landrace, cabbage, cauliflower, kale and Chinese kale, to detect loci of important traits, such as disease resistance, head morphology, nutritional quality and flowering/maturation time [38-42]. Several quantitative trait loci influencing head traits, including head weight, head height/width and floret height/width, have been identified, but the early constructed genetic maps are hard to unify $[23,42,43]$ due to the differences in plant germplasm, marker types and linkage group nomenclature and the lack of B. oleracea reference genomes before 2014. Using a double-haploid BolTBDH mapping population derived from Early Big (broccoli DH line) and TO1000DH3 (nonhead Chinese kale), Stansell et al. identified heading-quality QTLs, including BU_C04@51.5, BR_C09@49.5, HC_C09@48.8,HU_C09@48.8, HE_C09@47.7 and OQ_C09@49.5 (Table S1), and found genomic regions of approximately $49 \mathrm{Mb}$ on C09 harboring FLOWERING LOCUS C (FLC) homologs Bo9g173400 and Bogg173370, as hotspots contributing largely to over $40 \%$ phenotypic variance of the heading phenotype [33]. In another study, three head quality QTLs, $q C Q-2, q C Q-3$ and $q C Q-6$, associated with subtropical adaptation were identified [21]; and specific haplotype combinations of candidates BoFLC3 in the interval containing $q C Q-3$ and PERIANTHIA (PAN, a bZIP-transcription factor required for AGAMOUS activation) in the interval containing $q C Q-6$, were supposed to adapt broccoli to high ambient temperature and short daylength. Along with these key head-related traits, QTL mapping for bud morphology was also reported by Stansell et al. and Lin et al. [21,33]. These studies provide genetic information and breeding materials for improving broccoli varieties.

\subsubsection{Flowering Time}

Flowering is an important agronomic trait of broccoli, as it influences maturity, head quality, hybrid seed production and geographical region adaptation. Flowering time is con- 
sidered to be controlled by multiple QTLs. To detect QTLs/genes associated with this trait, segregation populations were generated by crossing broccoli with different germplasms, such as broccoli $\times$ cabbage, broccoli $\times$ Chinese kale and broccoli $\times$ broccoli. Different QTLs were detected in these studies, even using similar populations, such as broccoli $\times$ cabbage and broccoli $\times$ Chinese kale $[21,33,44-47]$. Most studies have implied that flowering is largely controlled by one or a few major QTLs [21,33,44-47]. As early as the late 1990s, using populations of broccoli (nonvernalization type) $\times$ cabbage (vernalization type), broccoli (late flowering type) $\times$ Chinese kale (early flowering type), several QTLs for flowering time were mapped [44-47]. Two subsequent studies used a similar population derived from broccoli $\times$ cabbage but obtained different results $[48,49]$, possibly due to the differences of the specific germplasms used and the planting environmental conditions. Okazaki et al. detected six QTLs controlling flowering time (from February to July, 2001, Niigata, Niigata Prefecture, Japan), among which the major QTL in the interval BRMS215-F2-R4b, accounting for $36.8 \%$ of the phenotypic variance and BoFLC2 in the interval is thought to be the candidate control of flowering time [48]. Similarly, using a broccoli $\times$ cabbage population, Shu et al. combined QTL-seq and a traditional linkage map to detect flowering time loci (from the spring of 2013 to the winter of 2014, Beijing China). A major QTL Ef2.1 is located on C02 2.65-2.68 Mb, responsible for early flowering and explaining $51.5 \%$ of the phenotypic variation, and a homolog of GROWTH-REGULATING FACTOR 6 (BolGRF6) is a possible candidate [49]. Using DH populations of broccoli $\times$ Chinese kale, Stansell et al. (2019) identified two QTLs DM_C03@6.4 and DM_C09@50.0 for days to maturity, two QTLs DF_C03@6.4 and DF_C09@50.0 for days to flowering, and the major QTLs DM_C09@50.0 and DF_C09@50.0 on C09 at approximately $50 \mathrm{Mb}$, explaining approximately $50 \%$ of the phenotypic variation [33].

Broccoli is usually sensitive and not feasible in high-temperature areas/seasons, which are thought to impede vernalization, resulting in defects in floral meristem development. Using tropical accessions in Taiwan, China, Lin et al. 2018 identified nonvernalizationresponsive QTLs that contribute to subtropical adaptation (high ambient temperature and short day length) [21]. The candidate gene BoFLC3 identified in the major QTL qDCI-3 may function as an alternative pathway for the control of flowering in temperate and tropical environments [21].

\subsubsection{Plant Architecture}

Plant architecture is a complex trait attributed to stem and leaf morphologies, including plant height, leaf size, leaf shape, leaf angle, petiole length and lateral shoot growth It affects the planting density, yield and quality of broccoli [50]. Several QTLs for plant architecture-relevant stem and leaf traits have been reported [23,27,32,51,52]. Before the release of reference genomes, researchers mapped QTLs associated with leaf lamina width on linkage groups C01 and C07 [51], stem width on LG5 [23], leaf apex on linkage groups C06 and C07 [43], leaf shape on linkage group C3 [43], leaf length on linkage group C7 [43], wing petiole length on linkage group C7 [43] and lobe number, wing number, leaf shape and lamina petiole length on linkage group C3 [43]. In recent years, in addition to focusing on heading traits, Stansell et al. mapped several QTLs for leaf morphology and lateral shoots. Four QTLs for leaf apex, two QTLs for leaf margin and leaf-associated hotspot genomic regions, Lea3 on C03 0.7-1.7 Mb and Lea7 on C07 37.0-39.5 Mb were identified. A GRF1-INTERACTING FACTOR 1 (GIF1) homolog (Bo7g093130) within major QTL LA_C07@36.6 may be responsible for the narrow leaf phenotype, and a LATE MERISTEM IDENTITY1 ortholog (BoLMI1, Bo3g002560) near the major LM_C03@0.7, explaining over $40 \%$ phenotype variation, may be responsible for leaf margin phenotype [33]. Three lateral shoot growth-associated QTLs, LT_C03@5.9, LT_C04@15.0 and LT_C09@9.0, are located on C03, C04 and C09, although no likely candidates were predicted [33]. Huang et al. constructed a genetic linkage map using a broccoli DH population and identified QTLs for plant height $(\mathrm{PH})$, maximum outer petiole length (PL) and leaf width (LW), including 
major QTLs phc1 for PH on chromosome 1, plc6-2 for PL on chromosome 6 and lwc3-1 for LW on chromosome 3 [52].

\subsubsection{Stem Development}

Broccoli hollow stem is an undesirable phenotypic disorder showing symptoms of cracks in the internal stem tissue [53,54]. It reduces the quality of broccoli products because hollow stems can result in (1) yield reduction, as harvested broccoli comprise partially edible stalks; (2) secondary pathogen infection and rotting of stems and florets $[38,39]$. The incidence of hollow stems increases when plants grow rapidly, triggered by, for example, high levels of nitrogenous and warm weather but also varies in different broccoli accessions, indicating that this trait is largely genetically determined and can be controlled by breeding resistant varieties $[53,54]$. However, relevant studies on this trait are very limited. Yu et al. constructed a genetic map using specific locus-amplified fragment (SLAF) sequencing in a double-haploid segregation population of broccoli and defined nine QTLs on C02, C03, C05, C06 and C09 for hollow stems, among which QHS. C09-2 could explain $14.1 \%$ of the phenotypic variation [55].

\subsubsection{Head Color}

Broccoli is rich in anthocyanin, an important nutritional value with antioxidant activity, can improve health, increase life expectancy and prevent diseases [56]. Anthocyanin accumulation in broccoli inflorescences, especially in septals, makes the appearance range from green/blue to purple. Some cultivars, such as 'Purple Sprouting Early', are selected for rich anthocyanin contents, producing obvious purple heads [56]. Purple traits in B. oleracea are attributed to the independent activation of Brassica oleracea MYB DOMAIN PROTEIN 2 (BoMYB2) in subspecies of cabbage, cauliflower, kohlrabi and possibly broccoli [57].

On the other hand, broccoli cultivars producing heads with green-purple color are considered not beautiful and would be less attractive to consumers than the completely green type, especially in the market of China [58]. This green-purple type is sensitive to temperature, and cool weather would induce and deepen the purple degree. Yu et al. mapped this purple sepal trait using a DH population and SLAF sequencing; three QTLs were detected, with a major locus, $q P H$. C01-2, located on linkage group (LG)1, and two loci, $q P H$. C01-4 and $q P H$. C01-5, located near $q P H$. C01-2 [59].

\subsection{Male Sterility and Fertility Restoration}

Broccoli displays obvious heterosis and most commercial broccoli varieties are F1 hybrids. The production of broccoli F1 hybrids depends on self-incompatibility before the early 21st century and now nearly completely depends on male sterility-based breeding systems $[11,12,59]$. Male sterility comprises cytoplasmic male sterility (CMS) and genic male sterility (GMS) [60]. Among them, Ogura CMS, with the advantages of complete male gamete abortion, maternal inheritance and easy transfer, is now the most widely studied and applied male sterility source in broccoli seed production [60,61]. Ogura CMS is a natural mutation found in radish populations [62], which is caused by a mitochondrial gene named orf138, and can be fully restored by the nuclear gene RFO (PPR-B) $[63,64]$.

Researchers have made efforts to introduce the CMS source to $B$. oleracea by distant hybridization and/or protoplast fusion, but the initially created CMSR1 and CMSR2 contain too much radish cytoplasm, displaying undesirable characteristics, including yellowing at low temperature, deformed flower shape and poor seed setting, which cannot be used in seed production [65-67]. Until the late 1990s, the American Asgrow company applied the method of asymmetric protoplast fusion to reduce the proportion of radish mitochondria, creating CMSR3 with normal fertility and pistil structure; this CMS has been transferred to many elite parent lines, playing a dominant role in the seed production of $B$. oleracea crops $[67,68]$. During the creation and transfer processes of Ogura CMS, specific orf138 PCR markers were developed for MAS [69]. Additional mitochondrial markers were developed to distinguish the CMS types; detected by these six orf138-related and two simple sequence 
repeat markers in 2016, Shu et al. divided 39 CMS broccoli accessions into five groups, and observed that CMSR3 constituted 79.49\% of the CMS accessions from China [67].

In addition to the Ogura CMS, GMS resources and GMS-based seed production systems were reported as promising alternatives [60,70-73]. A special dominant genic male sterility (DGMS) resource, 79-399-3, which arose in cabbage populations in China, has been successfully and widely applied in cabbage hybrid seed production $[61,72]$. The DGMS-based breeding system has been established in B. oleracea crops, including cabbage, broccoli and kohlrabi [61,72]. Compared with the Ogura CMS, the DGMS-based breeding system displayed advantages of much higher seed quality and yield [61]. However, its utilization is limited in broccoli, largely because homozygous DGMS plants must be preserved and reproduced by tissue culture, which is not effective for large-scale hybrid seed production [61]. Despite these disadvantages, this DGMS-based system has been preserved as an alternative for broccoli hybrid seed production. In recent decades, dozens of broccoli DGMS lines have been created, and several markers have been developed for MAS for the rapid creation of DGMS lines [61,74]. Shu et al. developed generic SSR markers linked to the male-sterile gene, with the marker scaffold10312a showed the highest accuracy of $\geq 96.43 \%$ [74]. By distinguishing the amplified products polyacrylamide gel, these markers were successfully used for identification of male and sterile plants in broccoli breeding lines DGMs8554, DGMs93219 and DGMs94174; enabled DGMS plants selection in the seedling stage. Han et al. developed a high-throughput kompetitive allele specific PCR (KASP) marker K6 with high accuracy and no genetic background bias applicable to all B. oleracea crops, including broccoli [61]. This marker was based on allele specific fluorescence on an Applied Biosystems Viia 7 real-time PCR system for high-throughput detection. In the DGMS-based breeding system, this marker was used for identifying homozygous DGMS plants from selfing progenies of heterozygous plants as an alternative to test crossing, which requires at least two years and additional labor in tissue culture [61]. These DGMS-specific markers enable effective selection in breeding programs.

On the other hand, there is increasing demand for the reutilization of CMS resources in B. oleracea crops. The Ogura CMS restorer gene RFO (PPR-B) was introduced from radish to rapeseed and recently to $B$. oleracea crops $[75,76]$. Liu et al. applied strategies of interspecific hybridization and backcrossing and introduced the RFO gene from rapeseed to broccoli. The foreground Rfo-specific markers BnRFO-AS2F/BnRFO-AS2F and BnRFOAS2F/BnRFO-NEW-R, were used for detecting Rfo-positive interspecific hybrids; and 28 background SSR markers were used for detecting true intergeneric hybrids and assessing the genetic backgrounds of $R f o$-positive interspecific hybrids. By evaluating polymorphism loci of the 28 background markers, the $\mathrm{BC} 2 R f o$-positive individuals were found closer to the broccoli's genetic background [76].

\subsection{Disease Resistance}

\subsubsection{Downy Mildew}

Downy mildew, caused by the obligate fungus Hyaloperonospora parasitica (Pers. Fr.), is a destructive disease that affects brassica crops, including broccoli [77,78]. Broccoli plants are often stunned or killed when infected with downy mildew at the young seedling stage or infection can result in quality reduction and yield loss at the adult stage $[79,80]$. The disease is prevalent in cool weather, with initial symptoms of light green-yellow lesions on the upper leaf surface and later on the undersurface; the spot enlarges and turns yellow; white fungi are visible on the undersurface of leaves under high humidity conditions $[79,80]$. High resistance to downy mildew both at the young and adult stages is present in some broccoli germplasms and is controlled by a single dominant locus [79,81-84]. Resistance loci were mapped and linkage markers were developed for MAS, but the gene has not been cloned [79,82,83]. Giovannelli et al. identified 8 RAPD (random amplification of polymorphic DNA) markers linked to downy mildew resistance in broccoli (cotyledon and true leaf stage), among which two, UBC3596 620 and OPM16 650 , were converted to SCAR (sequence characterized amplified regions) markers linked to the locus with 6.7 and 
3.3 cM [82]. Farinhó et al. mapped the locus Pp523 for downy mildew resistance to adult plants of broccoli and developed flanking RAPD markers OPK17_980 and AFLP marker AT. CTA_133/134, with genetic distances of $3.1 \mathrm{cM}$ and $3.6 \mathrm{cM}$, respectively [83]; in a later study, new AFLP markers were developed and some of them were more user-friendly SCAR and CAPS (cleaved amplified polymorphic sequence) markers; sequencing indicated that Pp523 is syntenic to the top arm end of Arabidopsis thaliana chromosome 1 [79]. We aligned the marker sequences to the broccoli HDEM reference genome [85] and found that the target $P p 523$ region is $49.29-50.68 \mathrm{Mb}$ on C8.

\subsubsection{Clubroot}

Clubroot, caused by the soil-borne pathogen Plasmodiophora brassicae, is one of the most devastating diseases of Brassica crops, including broccoli [86-88]. Plants infected by the pathogen form galls on roots, which prevent plant uptake of nutrients and water and become stunted and wilt under warm weather [89]. B. olearcea lacks germplasm highly resistant to clubroot, although it has been identified and studied for mining resistance loci/genes in its close relatives, such as turnip, radish and rapeseed [90-93]. The resistance gene $C R a$ has been introduced from $B$. rapa to $B$. olearcea by distant hybridization and MAS [94]; in this process CRa-specific markers SC2930-Q-FW/SC2930-RV were applied for detection of $C R a$ gene in the $\mathrm{F} 1$ and each backcross plants, enabled successful introgression of the $C R a$ gene into the cabbage inbred lines. In recent years, commercial broccoli varieties with the $C R a$ resistance gene, bred by the Syngenta Corporation, are available on the market of China, but the MAS process is not available.

While highly clubroot-resistant germplasms are lacking, some moderate clubroot resistance has been identified in B. oleracea [95-97]. There are two studies on genetic mapping for resistance loci related to broccoli, although both of them used broccoli as susceptible parents. These studies are useful for the rapid introduction of clubroot resistance from other subspecies/related species to broccoli with MAS [95,96]. Rocherieux et al. generated F2:3 segregation populations by crossing clubroot-resistant kale and clubroot-susceptible broccoli and constructed a restriction fragment length polymorphism (RFLP) based genetic map. The populations were infected by five isolates and two to five QTLs were identified depending on the isolates; one of these QTLs, $\mathrm{Pb}$-Bo1, showed broad-spectrum resistance detected in all isolates [95]. Using populations of crossing resistant double-haploid line (Anju) with a susceptible double-haploid line (GC), Nagaoka et al. identified five CR-QTLs, $p b-B o(A n j u) 1, P b B o(A n j u) 2, P b B o(A n j u) 3$ and $P b B o(A n j u) 4$ derived from Anju and $p b-B o(G C) 1$ from the susceptible parent GC; this study also provided specific primer sequences linked to CR loci and a comparison with known B. rapa CR genes [96].

\subsubsection{Black Rot}

Black rot, caused by the bacterium Xanthomonas campestris pv. campestris (Pam.) Dowson $(X c c)$, is also one of the most destructive diseases of brassica crops in the world [98,99]. The pathogen often invades plants through hydathodes and spreads through vascular tissue, forming V-shaped lesions at the leaf margins, causing systemic infection and great loss of quality and yield [98-100]. While some resistant plant resources have been reported in B. oleracea, few loci/genes have been identified [101-103]. Camargo et al. identified genomic regions associated with young and adult plant resistance to black rot in linkage groups 1, 2 and 9 using a population of black rot-resistant cabbage line BI-16 and susceptible inbred broccoli line OSU Cr-7 [38]. Doullah et al. identified two genomic regions on LG 2 and LG 9 significantly associated with resistance to black rot, with a disease rating of populations from susceptible broccoli green commet P09 and resistant Reiho P01 [104]. In a later study using the same plant materials, Tonu et al. improved the previous genetic map and identified three QTLs, XccBo(Reiho)1, XccBo(Reiho)2 and XccBo(Reiho)1, for resistance to black rot, and the major QTL, XccBo(Reiho)2, was from parent Reiho [105]; comparison using common markers of the previous study by Camargo et al. revealed that $X c c B o(R e i h o) 1$ and $X c c B o(G C) 1$ may be identical to the previously reported QTLs $[104,105]$. 
Iglesias-Bernabé et al. performed QTL analysis of black rot resistance (Xcc race 1) in the BolTBDH mapping population and identified four QTLs, including Xcc1.1 showing overlap with the previously reported cabbage resistance locus $B R Q T L-C 1 \_1, B R Q T L-C 1 \_2$ [106], Xcc6.1 showing overlap with BRQTL-C6, Xcc8.1 showing overlap with XccBo(Reiho)2 [105] and a novel locus, Xcc9.1 [107]; in addition, this study indicated that resistance might be related to the synthesis of secondary metabolites [107].

\subsection{Secondary Metabolites}

Broccoli contains a number of beneficial secondary metabolites, including glucosinolates/sulforaphane, carotenoids, phenolic acids and flavonoids. Several loci/genes regulating the accumulation of these compounds in broccoli have been identified. Genetic models of secondary metabolite biosynthesis in Arabidopsis provide a convenient tool for homologous studies in broccoli $[108,109]$. Via a homologous cloning strategy, some broccoli genes are isolated directly, including cytochrome P450 79F1 (CYP79F1), cytochrome P450 83A1 (CYP83A1), UDP-glucosyltransferase $74 B 1$ (UGT74B1), sulfotransferase 18 (ST5b) and flavincontaining monooxygenase GS-OX1 (FMOGS-OX1), cytochrome P45083B1 (BoCYP83B1), BoMYB51, GSL-PRO, GSL-ELONG, GSL-ALK, GSL-OH, Myb28 and BoMYB51 for glucosinolate biosynthesis [109-113], and BoPAL, BoDFR, BoTT8 and BoTTG1 for anthocyanin biosynthesis [114]. Genetic loci determining the variation in these secondary metabolites were also detected by genetic mapping. Sotelo et al. performed genetic analysis to identify the genome regions regulating glucosinolate biosynthesis in the $\mathrm{DH}$ mapping population BolTBDH and detected eighty-two significant QTLs for individual and total glucosinolate synthesis in leaves, seeds and flower buds, and QTL9.2 (proposed candidate as GSL-ALK) plays a central role in determining glucosinolate variation, showing epistatic interactions with other loci [115]. Brown et al. constructed a genetic linkage map with a broccoli mapping population, identified 14 QTLs associated with the accumulation of aliphatic, indolic or aromatic glucosinolates in florets, and a locus GSL12 on C09 explains approximately $40 \%$ of the phenotypic variability of progoitrin [116]. Li et al. performed genetic mapping for sulforaphane metabolism with a DH population; 18 QTLs for sulforaphane metabolism in broccoli florets were identified, and six QTLs among them were detected in more than one environment [117]. Using the same population previously reported [116], Brown et al. constructed a genetic linkage map with an SNP array and identified three QTLs for carotenoid variation in broccoli florets [118]. Gardner et al. performed QTL analysis saturated with SNP markers in an Illumina $60 \mathrm{~K}$ array for total phenolic concentration and its individual components in the population previously reported by Brown et al. [118] and obtained twenty-three loci identified in at least two analyses [119]. In the BolTBDH mapping population, 33 QTLs were identified controlling phenolic concentrations in leaves, flower buds and seeds [120]. In addition, transcriptome analyses were performed to identify differentially expressed genes related to glucosinolate metabolism in broccoli seeds, sprouts and byproducts [121-123].

\subsection{Development of Omics Research}

Advances in techniques and reduced costs of high-throughput next- and third-generation sequencing have brought high-throughput tools for genomic-related studies and the improvement of broccoli. In 2014, B. oleracea draft genome-based short reads of the next generation were released [124,125]; in 2018, the first broccoli (HDEM) reference genome, a high-quality daft genome based on third-generation nanopore long reads and optical maps, was accessible [85]. These studies provided information on genome duplication and gene divergence and the direct prediction of genes related to phytochemicals and morphological variations and, as mentioned above, provided a reference for high density marker development $[97,116,118]$. Bulked-segregant analysis combined with whole genome resequencing (BSA-seq) for rapid gene/QTL mapping and candidate searching $[13,32]$ and omics-related studies exploring differentially expressed genes/miRNAs related to important traits [26-30,121-123]. In addition, high-throughput strategies promote KASP marker-based fingerprinting for the essential 
broccoli germplasm [126], genetic diversity and population structure analysis for broccoli cultivars [11,127], and the genomic and morphological domestication syndrome of broccoli calabrese landraces, hybrids and sprouting broccoli [11].

\subsection{Genome Editing}

Genome editing is a powerful tool for efficient and targeted genome manipulations in living organisms. Depending on the genome editing tools, four engineered nucleases were developed: Meganucleases [128], zinc finger nucleases (ZFNs) [129], transcription activatorlike effector-based nucleases (TALENs) [130] and short palindromic repeat (CRISPR)associated protein (Cas9) systems [131,132]. CRISPR/Cas9 has proven to be a cost-effective and versatile tool for precise and efficient genome editing and in recent years, it has been extensively studied and applied to manipulate desired genes in plants [133]. While it has been realized in some B. oleracea crops $[134,135]$, genome editing by CRISPR/Cas9 has not succeeded in complete broccoli background plants. Only one study applied this tool to broccoli-related plant material DH1012, a doubled haploid genotype from the crossing of B. oleracea alboglabra (A12DHd) with B. oleracea italica (Green Duke GDDH33), targeting BolC.GA4.a (Bol038154), resulting in dwarf stature [136,137].

\subsection{Genetic Transformation}

Agrobacterium-mediated transformation in broccoli was first reported by Metz et al. [138]. In the last decade, this genetic engineering tool has been applied for improving broccoli regarding (1) insect resistance by the genes $c r y 1 A(c)$, cry $1 C$ and $c r y I A(b)$; (2) fungal resistance by the Trichoderma harzianum endochitinase gene, $P R-1$ and $P R-2$; (3) abiotic stress resistance by AtHSP101; (4) herbicide resistance by Bar gene; (5) prolonged shelf-life/delayed postharvest yellowing by ipt (isopentenyl transferase) gene, ACC synthase 1, BoCLH1 and ACC oxidase gene; and (6) flowering control by CYP86MF, SLG, FCA and CONSTANS, which has been reviewed by Kumar and Srivastava in 2016 [1]. Thus, we review the advances of broccoli transgenic improvement in recent years (Table 1 ).

Table 1. Broccoli improvement by genetic transformation in recent years.

\begin{tabular}{|c|c|c|c|c|}
\hline Gene Transferred & Origin & Recipient Plant & Performance & References \\
\hline BoAPX & broccoli & broccoli & $\begin{array}{l}\text { enhanced resistance to downy } \\
\text { mildew } \\
\text { enhanced tolerance to heat stress }\end{array}$ & [139] \\
\hline BoWRKY6 & broccoli & broccoli & $\begin{array}{l}\text { enhanced resistance to downy } \\
\text { mildew }\end{array}$ & [140] \\
\hline BoiCesA (RNAi) & broccoli & broccoli & $\begin{array}{l}\text { enhanced salt tolerance; dwarf and } \\
\text { smaller leaves }\end{array}$ & [141] \\
\hline $\mathrm{BoC} 3 \mathrm{H}$ & broccoli & broccoli & enhanced salt stress tolerance & [142] \\
\hline $\mathrm{BoC} 3 \mathrm{H} 4$ & broccoli & broccoli & $\begin{array}{l}\text { enhanced salt stress tolerance; } \\
\text { more susceptible to } S \text {. sclerotiorum }\end{array}$ & [143] \\
\hline BoERF1 & broccoli & broccoli & $\begin{array}{c}\text { enhanced salt stress tolerance; } \\
\text { enhanced resistance to Sclerotinia } \\
\text { stem rot }\end{array}$ & [144] \\
\hline cryIAa & $\begin{array}{l}\text { Bacillus } \\
\text { thuringiensis }\end{array}$ & broccoli & resistance to diamondback moth & [145] \\
\hline BoMYB29 & wild B. oleracea & $\begin{array}{l}\text { DH line AG1012, (partial } \\
\text { broccoli background) }\end{array}$ & increased glucosinolate content & [146] \\
\hline BoTSB1, BoTSB2 & broccoli & Arabidopsis & increased glucosinolate content & [147] \\
\hline $\begin{array}{l}\text { BroMYB28 (transient } \\
\text { overexpression) }\end{array}$ & broccoli & broccoli & increased glucoraphanin content & [148] \\
\hline
\end{tabular}


Table 1. Cont.

\begin{tabular}{ccccc}
\hline Gene Transferred & Origin & Recipient Plant & Performance & References \\
\hline MAM1 & broccoli & broccoli & increased sulforaphane content & [149] \\
\hline FMOGS-OX2 & broccoli & broccoli & increased sulforaphane content & [149] \\
\hline Myrosinase & broccoli & broccoli & increased sulforaphane content & [149] \\
\hline BoiDAD1F (RNAi) & broccoli & broccoli & recoverable male sterility & [150] \\
\hline bol-miR171b & broccoli & broccoli & $\begin{array}{c}\text { nearly completely male sterile and } \\
\text { increased the chlorophyll content }\end{array}$ \\
\hline
\end{tabular}

\subsubsection{Transgenic Breeding for Fungal Resistance}

In two independent studies, Jiang et al. generated transgenic broccoli plants overexpressing the cytosolic ascorbate peroxidase gene BoAPX and the WRKY transcription factor gene BoWRKY6; both of them obtained enhanced resistance to downy mildew $[139,140]$. $B o A P X$-overexpressing broccoli, with a lower level of electrical conductivity and a higher level of APX enzyme activity, exhibited significantly higher resistance to Hyaloperonospora parasitica infection, as well as to heat stress, than wild-type plants [139]. BoWRKY6overexpressing broccoli exhibited significantly increased resistance to downy mildew but varied from low to very high [140]; two of them, lines BWK14 and BWK31, exhibited very high resistance to downy mildew [140].

\subsubsection{Transgenic Breeding for Abiotic Stress Resistance}

Li et al. generated RNAi transgenic broccoli lines targeting the cellulose synthase gene BoiCesA; the BoiCesA knockdown plants showed a loss of cellulose content and significantly enhanced salt tolerance, and the expression of related genes (BoiProH, BoiPIP2;2, BoiPIP2;3) was significantly changed but also displayed phenotypic defects characterized by dwarfs and smaller leaves [141].

In three independent studies, Jiang et al. reported that the overexpression of the $\mathrm{C} 3 \mathrm{H}$-type zinc finger genes $\mathrm{BoC} 3 \mathrm{H}$ and $\mathrm{BoC} 3 \mathrm{H} 4$ and the ethylene response transcription factor gene BoERF1 enhanced salt stress tolerance [142-144]. The BoC3H-overexpression lines exhibited higher germination rates, dry weight and chlorophyll content under salt stress and less cell death in the leaves due to the decreased hydrogen peroxide level, relative electrical conductivity and malondialdehyde contents but increased free proline content and catalase, peroxidase and superoxide dismutase enzyme activities [142]. The $\mathrm{BoC} 3 \mathrm{H} 4$-overexpression lines exhibited increased salinity stress tolerance, with an increase in proline and $\mathrm{H}_{2} \mathrm{O}_{2}$ and a decrease in chlorophyll loss, MDA and REC compared with WT plants; however, the lines were more susceptible to $S$. sclerotiorum, possibly due to the inhibited expression of the BoPDF1.2 gene [143]. The BoERF1-overexpression lines exhibited a higher seed germination rate and less chlorophyll loss under salt stress, with less cell death in the leaves similar to the $\mathrm{BoC} 3 \mathrm{H}$-overexpression lines; in addition, the transgenic lines showed enhanced resistance to Sclerotinia stem rot [144].

\subsubsection{Transgenic Breeding for Insect Resistance}

Transgenic broccoli for insect resistance was extensively studied in the late 1990s and the beginning of the 21st century [1], but in recent years there have been few related studies. Kumar et al. generated transgenic broccoli overexpressing cryIAa, which showed effective resistance to infestation by diamondback moth (Plutella xylostella) larvae [145].

\subsubsection{Transgenic Breeding for Enriched Glucosinolate/Sulforaphane Content}

In recent years, improving the anticancer metabolite glucosinolate/sulforaphane content in broccoli by the genetic engineering of biosynthesis-/regulation-related genes has increased [146-149,152]. Zuluaga et al. reported that the overexpression of BoMYB29 in DH line AG1012 resulted in the upregulation of the aliphatic glucosinolate pathway and 
higher production of methylsulphinylalkyl glucosinolates, including glucoraphanin [146]. $\mathrm{Li}$ et al. isolated two tryptophan synthase beta subunit (TSB) genes from broccoli and generated overexpression lines of BoTSB1 or BoTSB2 in Arabidopsis, which showed accumulation of tryptophan, indole-3-acetic acid (IAA) and indole glucosinolates; this study provides a target for improving glucosinolates, but no broccoli transgenic plants were generated [147]. Studies on BroMYB28 revealed its possible role in the biosynthesis of glucoraphanin [152], but its function was not proven in broccoli until 2019 [148]. Agrobacterium-mediated transient overexpression of BroMYB28 in broccoli results in the accumulation of glucoraphanin [148]. Cao et al. generated transgenic broccoli by overexpressing MAM1, FMO $\mathrm{GS}_{-O X 2}$ and Myrosinase independently or in triple [149]. Compared with wild-type plants, independent transgenes of MAM1 FMO ${ }_{G S-O X 2}$ and Myrosinase enhanced sulforaphane content by 1.7-3.4-, 1.6-2.7- and 3.7-fold, while transgenic plants with the triple gene enhanced sulforaphane content by 1.86-5.5-fold [149].

\subsubsection{Transgenic Breeding for Manipulating Male Fertility}

Creation of a new male-sterile type by genetic engineering strategies can rapidly provide alternative resources for hybrid seed production. Male-sterile transgenic broccoli was reported by Chen et al. via RNAi of the jasmonic acid pathway gene BoiDAD1F [150]. These transgenic plants showed male sterility under normal conditions but recovered to fertility when treated with exogenous JA and were thus suitable for utilization in a two-line seed production system [150]. Li et al. reported that the overexpression of a microRNA bol-miR171b in broccoli resulted in nearly complete male sterility and increased the chlorophyll content [151].

\section{Conclusions and Future Perspectives}

In recent years, progress has been made in the molecular breeding of broccoli for agronomic traits, secondary metabolites, male sterility, abiotic stress resistance, disease resistance and insect resistance. MAS facilitates the breeding of heat-stress-resistant varieties and clubroot-resistant varieties. However, the molecular breeding of broccoli is still restrained by a lack of basic research and an unknown genetic basis of most desirable traits. Future research on the molecular breeding of broccoli may pay attention to the following aspects.

\subsection{Mining Functional Loci/Genes}

Some linked markers and mapped genes/QTLs for desirable traits have been reported, and with the development of sequencing technology in recent years, candidates have been predicted for mapped genes/QTLs. Omics technologies, such as transcriptomics, proteomics and metabolomics, have been employed to understand the mechanism of desirable traits. Despite efforts, quite a few genes in broccoli have been cloned and functionally verified. Further research should focus on mining and functionally verifying more genes/QTLs for guiding and promoting the breeding work of broccoli: (1) As the most desirable traits in broccoli are controlled by complex QTLs, secondary mapping populations, including near-isogenic lines, introgression lines and chromosome segment substitution lines, should be developed for fine mapping and isolation of these genes; (2) by reverse genetics approaches, released databases and advanced sequencing technology can be used to identify more functional genes; and (3) the obtained target genes, neither from fine mapping nor homology cloning, should be verified by transient expression or genetic transformation.

\subsection{Improving Broccoli by Landraces or Other B. oleracea Subspecies}

Modern broccoli has very narrow genetic diversity, which may cause undesirable quality, yield and resistance. Broccoli landraces (especially from Italy) and other subspecies provide diverse genetic resources with promising traits, such as differential heading type, differential flowering/maturation time, high glucosinolate content and strong disease 
resistance. Desirable genes can be introduced by MAS from landraces/different subspecies to breeding materials to improve the quality and extend the genetic diversity of broccoli. A particular case is the head compactness of calabrese broccoli, the most popular broccoli type; in recent decades, head compactness of this broccoli has been significantly enhanced for easy transport and storage, which may be improved via genomic fragment introgression from cauliflower (no published literature).

\subsection{Introducing Disease Resistance Genes from Related Species}

Broccoli lacks resistance to some devastating diseases, such as clubroot and black rot. To guard broccoli genotypes against these diseases, distant hybridization and MAS can be used to introduce pyramid resistance genes/loci from related species. The clubroot pathogen $P$. brassicae evolved many physiological races showing different infection responses on host plants. Only one resistant locus, $C R a$ for race 4 , has been introduced from B. rapa, which is not enough for sustainable production of broccoli under the threat of other P. brassicae races. More resistance genes/loci should be introduced from related species, such as turnip, radish and rapeseed, and pyramided in broccoli. For black rot disease, strong resistance sources have been reported in the A and B genomes of Brassica species, and moderate clubroot resistance has been reported in the $\mathrm{C}$ genome of cabbage. These resistance genes/loci can be introduced from Brassica carinata and cabbage to broccoli.

\subsection{Improving the CRISPR/Cas9 Genome Editing System}

The CRISPR/Cas9 system has been proven to be a highly efficient genome editing method in plants. In recent years, this genome editing system has been successfully applied in many crops, including rice, maize, soybean and tomato, for gene function studies and crop improvement, such as high yield, disease resistance, herbicide resistance, ideal plant architecture and other desirable traits. However, the CRISPR/Cas9 system has not been established in broccoli; thus, future studies should pay more attention to improving and employing the CRISPR/Cas9 system for broccoli improvement.

Supplementary Materials: The following are available online at https://www.mdpi.com/article/10 .3390/horticulturae7090280/s1, Table S1: Genetic mapping of genes/QTLs in broccoli.

Author Contributions: Conceptualization, F.H.; writing-original draft preparation, F.H.; writingreview and editing, Y.L., Z.F., L.Y., M.Z., Y.Z., H.L., Y.W. and J.J.; supervision, F.H.; project administration, Z.L.; funding acquisition, Z.F. and Z.L. All authors have read and agreed to the published version of the manuscript.

Funding: This research was funded by grants from the Central Public-interest Scientific Institution Basal Research Fund (Grant No. IVF-BRF2020003, IVF-BRF2021003), the China Agriculture Research System (Grant No. CARS-23-08A), the Agricultural Science and Technology Innovation Program (Grant No. ASTIP), and the State Key Laboratory of Vegetable Germplasm Innovation (Grant No. SKL-VGI).

Institutional Review Board Statement: Not applicable.

Informed Consent Statement: Not applicable.

Conflicts of Interest: The authors declare no conflict of interest.

\section{References}

1. Kumar, P.; Srivastava, D.K. Biotechnological advancement in genetic improvement of broccoli (Brassica oleracea L. var. italica), an important vegetable crop. Biotechnol. Lett. 2016, 38, 1049-1063. [CrossRef] [PubMed]

2. Luo, F.; Fang, H.-X.; Wei, B.-D.; Cheng, S.-C.; Zhou, Q.; Zhou, X.; Zhang, X.; Zhao, Y.-B.; Ji, S.-J. Advance in yellowing mechanism and the regulation technology of post-harvested broccoli. Food Qual. Saf. 2020, 4, 107-113. [CrossRef]

3. Vallejo, F.; Garcia-Viguera, C.; Tomas-Barberan, F. Changes in Broccoli (Brassica oleracea L. var. italica) Health-Promoting Compounds with Inflorescence Development. J. Agric. Food Chem. 2003, 51, 3776-3782. [CrossRef] [PubMed]

4. Vallejo, F.; Tomas-Barberan, F.; Ferreres, F. Characterisation of flavonols in broccoli (Brassica oleracea L. var. italica) by liquid chromatography-UV diode-array detection-electrospray ionisation mass spectrometry. J. Chromatogr. A 2004, 1054, 181-193. [CrossRef] [PubMed] 
5. Shapiro, T.A.; Fahey, J.W.; Wade, K.L.; Stephenson, K.K.; Talalay, P. Chemoprotective Glucosinolates and Isothiocyanates of Broccoli Sprouts. Cancer Epidemiol. Prev. Biomark. 2001, 10, 501-508.

6. Buck, P.A. Origin and taxonomy of broccoli. Econ. Bot. 1956, 10, 250-253. [CrossRef]

7. Massie, I.H.; Astley, D.; King, G.J. Patterns of genetic diversity and relationships between regional groups and populations of Italian landrace cauliflower and broccoli (Brassica oleracea L. var. botrytis L. and var. italica Plenck). Acta Hort. 1996, 407, 45-54. [CrossRef]

8. Ciancaleoni, S.; Chiarenza, G.L.; Raggi, L.; Branca, F.; Negri, V. Diversity characterisation of broccoli (Brassica oleracea L. var. italica Plenck) landraces for their on-farm (in situ) safeguard and use in breeding programs. Genet. Resour. Crop. Evol. 2013, 61, 451-464. [CrossRef]

9. Maggioni, L.; Von Bothmer, R.; Poulsen, G.; Lipman, E. Domestication, diversity and use of Brassica oleracea L., based on ancient Greek and Latin texts. Genet. Resour. Crop. Evol. 2017, 65, 137-159. [CrossRef]

10. Branca, F.; Chiarenza, G.L.; Cavallaro, C.; Gu, H.; Zhao, Z.; Tribulato, A. Diversity of Sicilian broccoli (Brassica oleracea var. italica) and cauliflower (Brassica oleracea var. botrytis) landraces and their distinctive bio-morphological, antioxidant, and genetic traits. Genet. Resour. Crop. Evol. 2017, 65, 485-502. [CrossRef]

11. Stansell, Z.; Björkman, T. From landrace to modern hybrid broccoli: The genomic and morphological domestication syndrome within a diverse B. oleracea collection. Hortic. Res. 2020, 7, 1-17. [CrossRef] [PubMed]

12. Li, Z.; Mei, Y.; Liu, Y.; Fang, Z.; Yang, L.; Zhuang, M.; Zhang, Y.; Lv, H. The evolution of genetic diversity of broccoli cultivars in China since 1980. Sci. Hortic. 2019, 250, 69-80. [CrossRef]

13. Branham, S.E.; Farnham, M.W. Identification of heat tolerance loci in broccoli through bulked segregant analysis using whole genome resequencing. Euphytica 2019, 215, 34. [CrossRef]

14. Kumar, R.; Kandpal, K. Influence of foliar fertilization of boron on broccoli (Brassica oleracea var. italica) in boron deficient soil of Doon Valley, India. Progress. Hortic. 2017, 49, 65. [CrossRef]

15. Branham, S.E.; Stansell, Z.J.; Couillard, D.M.; Farnham, M.W. Quantitative trait loci mapping of heat tolerance in broccoli (Brassica oleracea var. italica) using genotyping-by-sequencing. Theor. Appl. Genet. 2017, 130, 529-538. [CrossRef]

16. Farnham, M.W.; Bjorkman, T. Breeding Vegetables Adapted to High Temperatures: A Case Study with Broccoli. HortScience 2011, 46, 1093-1097. [CrossRef]

17. Björkman, T.; Pearson, K.J. High temperature arrest of inflorescence development in broccoli (Brassica oleracea var. italica L.). J. Exp. Bot. 1998, 49, 101-106. [CrossRef]

18. Heather, D.; Sieczka, J.; Dickson, M.; Wolfe, D. Heat Tolerance and Holding Ability in Broccoli. J. Am. Soc. Hortic. Sci. 1992, 117, 887-892. [CrossRef]

19. Atallah, S.S.; Gómez, M.I.; Björkman, T. Localization effects for a fresh vegetable product supply chain: Broccoli in the eastern United States. Food Policy 2014, 49, 151-159. [CrossRef]

20. Ward, B.; Smith, P.; James, S.; Stansell, Z.; Farnham, M. Increasing Plant Density in Eastern United States Broccoli Production Systems to Maximize Marketable Head Yields. Horttechnology 2015, 25, 330-334. [CrossRef]

21. Lin, Y.-R.; Lee, J.-Y.; Tseng, M.-C.; Lee, C.-Y.; Shen, C.-H.; Wang, C.-S.; Liou, C.-C.; Shuang, L.-S.; Paterson, A.H.; Hwu, K.-K. Subtropical adaptation of a temperate plant (Brassica oleracea var. italica) utilizes non-vernalization-responsive QTLs. Sci. Rep. 2018, 8, 13609. [CrossRef]

22. Astarini, I.A.; Defiani, M.R.; Suriani, N.L.; Griffiths, P.; Stefanova, K.; Siddique, K. Adaptation of broccoli (Brassica oleracea var. italica L.) to high and low altitudes in Bali, Indonesia. Biodiversitas J. Biol. Divers. 2020, 21, 5263-5269. [CrossRef]

23. Lin, K.H.; Chang, L.C.; Lai, C.D.; Lo, H.F. AFLP mapping of quantitative trait loci influencing seven head-related traits in broccoli (Brassica oleracea var. italica). J. Hortic. Sci. Biotechnol. 2013, 88, 257-268. [CrossRef]

24. Lin, K.-H.; Huang, H.-C.; Lin, C.-Y. Cloning, expression and physiological analysis of broccoli catalase gene and Chinese cabbage ascorbate peroxidase gene under heat stress. Plant Cell Rep. 2010, 29, 575-593. [CrossRef]

25. Chiang, C.-M.; Chen, S.-P.; Chen, L.-F.O.; Chiang, M.-C.; Chien, H.-L.; Lin, K.-H. Expression of the broccoli catalase gene (BoCAT) enhances heat tolerance in transgenic Arabidopsis. J. Plant Biochem. Biotechnol. 2013, 23, 266-277. [CrossRef]

26. Chen, C.-C.; Fu, S.-F.; Norikazu, M.; Yang, Y.-W.; Liu, Y.-J.; Ikeo, K.; Gojobori, T.; Huang, H.-J. Comparative miRNAs analysis of Two contrasting broccoli inbred lines with divergent head-forming capacity under temperature stress. BMC Genom. 2015, 16, 1026. [CrossRef] [PubMed]

27. Lin, C.-W.; Fu, S.-F.; Liu, Y.-J.; Chen, C.-C.; Chang, C.-H.; Yang, Y.-W.; Huang, H.-J. Analysis of ambient temperature-responsive transcriptome in shoot apical meristem of heat-tolerant and heat-sensitive broccoli inbred lines during floral head formation. BMC Plant Biol. 2019, 19, 3. [CrossRef]

28. Lin, H.-H.; Lin, K.-H.; Chen, S.-C.; Shen, Y.-H.; Lo, H.-F. Proteomic analysis of broccoli (Brassica oleracea) under high temperature and waterlogging stresses. Bot. Stud. 2015, 56, 1-11. [CrossRef] [PubMed]

29. Tian, Y.; Tian, Y.; Luo, X.; Zhou, T.; Huang, Z.; Liu, Y.; Qiu, Y.; Hou, B.; Sun, D.; Deng, H.; et al. Identification and characterization of microRNAs related to salt stress in broccoli, using high-throughput sequencing and bioinformatics analysis. BMC Plant Biol. 2014, 14, 1-13. [CrossRef]

30. Torres-Contreras, A.M.; Senés-Guerrero, C.; Pacheco, A.; González-Agüero, M.; Ramos-Parra, P.A.; Cisneros-Zevallos, L.; JacoboVelázquez, D.A. Genes differentially expressed in broccoli as an early and late response to wounding stress. Postharvest Biol. Technol. 2018, 145, 172-182. [CrossRef] 
31. Lee, J.; Yang, K.; Lee, M.; Kim, S.; Kim, J.; Lim, S.; Kang, G.-H.; Min, S.R.; Kim, S.-J.; Park, S.U.; et al. Differentiated cuticular wax content and expression patterns of cuticular wax biosynthetic genes in bloomed and bloomless broccoli (Brassica oleracea var. italica). Process. Biochem. 2015, 50, 456-462. [CrossRef]

32. Branham, S.E.; Farnham, M.W. Genotyping-by-sequencing of waxy and glossy near-isogenic broccoli lines. Euphytica 2017, 213, 84. [CrossRef]

33. Stansell, Z.; Farnham, M.; Björkman, T. Complex Horticultural Quality Traits in Broccoli Are Illuminated by Evaluation of the Immortal BolTBDH Mapping Population. Front. Plant Sci. 2019, 10, 1104. [CrossRef] [PubMed]

34. Duclos, D.V.; Bjoerkman, T. Meristem identity gene expression during curd proliferation and flower initiation in Brassica oleracea. J. Exp. Bot. 2008, 59, 421-433. [CrossRef]

35. Fujime, Y.; Okuda, N. The physiology of flowering in brassicas, especially about cauliflower and broccoli. Acta Hortic. 1996, 247-254. [CrossRef]

36. Carr, S.M.; Irish, V.F. Floral homeotic gene expression defines developmental arrest stages in Brassica oleracea L. vars. botrytis and italica. Planta 1997, 201, 179-188. [CrossRef]

37. Smith, L.B.; King, G.J. The distribution of BoCAL-a alleles in Brassica oleracea is consistent with a genetic model for curd development and domestication of the cauliflower. Mol. Breed. 2000, 6, 603-613. [CrossRef]

38. Camargo, L.; Williams, P.; Osborn, T. Mapping of quantitative trait loci controlling resistance of Brassica oleracea to Xanthomonas campestris pv. campestris in the field and greenhouse. Phytopathology 1995, 85, 1296-1300. [CrossRef]

39. Bohuon, E.J.R.; Keith, D.J.; Parkin, I.A.P.; Sharpe, A.G.; Lydiate, D.J. Alignment of the conserved C genomes of Brassica oleracea and Brassica napus. Theor. Appl. Genet. 1996, 93, 833-839. [CrossRef]

40. Kianian, S.F.; Quiros, C.F. Generation of a Brassica oleracea composite RFLP map: Linkage arrangements among various populations and evolutionary implications. Theor. Appl. Genet. 1992, 84, 544-554. [CrossRef] [PubMed]

41. Slocum, M.K.; Figdore, S.S.; Kennard, W.C.; Suzuki, J.Y.; Osborn, T.C. Linkage arrangement of restriction fragment length polymorphism loci in Brassica oleracea. Theor. Appl. Genet. 1990, 80, 57-64. [CrossRef]

42. Brown, A.F.; Jeffery, E.; Juvik, J.A. A Polymerase Chain Reaction-based Linkage Map of Broccoli and Identification of Quantitative Trait Loci Associated with Harvest Date and Head Weight. J. Am. Soc. Hortic. Sci. 2007, 132, 507-513. [CrossRef]

43. Walley, P.G.; Carder, J.; Skipper, E.; Mathas, E.; Lynn, J.; Pink, D.; Buchanan-Wollaston, V. A new broccoli x broccoli immortal mapping population and framework genetic map: Tools for breeders and complex trait analysis. Theor. Appl. Genet. 2012, 124, 467-484. [CrossRef]

44. Kennard, W.C.; Slocum, M.K.; Figdore, S.S.; Osborn, T.C. Genetic analysis of morphological variation in Brassica oleracea using molecular markers. Theor. Appl. Genet. 1994, 87, 721-732. [CrossRef] [PubMed]

45. Camargo, L.; Osborn, T. Mapping loci controlling flowering time in Brassica oleracea. Theor. Appl. Genet. 1996, 92, 610-616. [CrossRef] [PubMed]

46. Bohuon, E.J.R.; Ramsay, L.D.; Craft, J.A.; Arthur, A.E.; Marshall, D.; Lydiate, D.J.; Kearsey, M.J. The Association of Flowering Time Quantitative Trait Loci with Duplicated Regions and Candidate Loci in Brassica oleracea. Genetics 1998, 150, 393-401. [CrossRef] [PubMed]

47. Rae, A.M.; Howell, E.C.; Kearsey, M.J. More QTL for flowering time revealed by substitution lines in Brassica oleracea. Heredity 1999, 83, 586-596. [CrossRef]

48. Okazaki, K.; Sakamoto, K.; Kikuchi, R.; Saito, A.; Togashi, E.; Kuginuki, Y.; Matsumoto, S.; Hirai, M. Mapping and characterization of FLC homologs and QTL analysis of flowering time in Brassica oleracea. Theor. Appl. Genet. 2006, 114, 595-608. [CrossRef] [PubMed]

49. Shu, J.S.; Liu, Y.M.; Zhang, L.L.; Li, Z.S.; Fang, Z.Y.; Yang, L.M.; Zhuang, M.; Zhang, Y.Y.; Lv, H.H. QTL-seq for rapid identification of candidate genes for flowering time in broccoli x cabbage. Theor. Appl. Genet. 2018, 131, 917-928. [CrossRef] [PubMed]

50. Hale, A.L.; Farnham, M.W.; Nzaramba, M.N.; Kimbeng, C.A. Heterosis for horticultural traits in Broccoli. Theor. Appl. Genet. 2007, 115, 351-360. [CrossRef] [PubMed]

51. Lan, T.-H.; Paterson, A.H. Comparative Mapping of Quantitative Trait Loci Sculpting the Curd of Brassica oleracea. Genetics 2000, 155, 1927-1954. [CrossRef]

52. Huang, J.; Sun, J.; Liu, E.; Yuan, S.; Liu, Y.; Han, F.; Li, Z.; Fang, Z.; Yang, L.; Zhuang, M.; et al. Mapping of QTLs detected in a broccoli double diploid population for planting density traits. Sci. Hortic. 2021, 277, 109835. [CrossRef]

53. Boersma, M.; Gracie, A.; Brown, P. Evidence of mechanical tissue strain in the development of hollow stem in broccoli. Sci. Hortic. 2013, 164, 353-358. [CrossRef]

54. Boersma, M.; Gracie, A.J.; Brown, P.H. Relationship between growth rate and the development of hollow stem in broccoli. Crop. Pasture Sci. 2009, 60, 995-1001. [CrossRef]

55. Yu, H.; Wang, J.; Zhao, Z.; Sheng, X.; Shen, Y.; Branca, F.; Gu, H. Construction of a High-Density Genetic Map and Identification of Loci Related to Hollow Stem Trait in Broccoli (Brassic oleracea L. italica). Front. Plant Sci. 2019, 10, 10. [CrossRef] [PubMed]

56. Chaudhary, A.; Choudhary, S.; Sharma, U.; Vig, A.P.; Singh, B.; Arora, S. Purple head broccoli (Brassica oleracea L. var. italica Plenck), a functional food crop for antioxidant and anticancer potential. J. Food Sci. Technol. 2018, 55, 1806-1815. [CrossRef] [PubMed]

57. Yan, C.; An, G.; Zhu, T.; Zhang, W.; Zhang, L.; Peng, L.; Chen, J.; Kuang, H. Independent activation of the BoMYB2 gene leading to purple traits in Brassica oleracea. Theor. Appl. Genet. 2018, 132, 895-906. [CrossRef] [PubMed] 
58. Yu, H.; Wang, J.; Sheng, X.; Zhao, Z.; Shen, Y.; Branca, F.; Gu, H. Construction of a high-density genetic map and identification of loci controlling purple sepal trait of flower head in Brassica oleracea L. italica. BMC Plant Biol. 2019, 19, 228. [CrossRef] [PubMed]

59. Reshma, V.; Adarsh, M.; Dhanush, K. Development of hybrids in cole crops: A review. Plant Arch. 2018, 18, 1-11.

60. Han, F.; Yuan, K.; Kong, C.; Zhang, X.; Yang, L.; Zhuang, M.; Zhang, Y.; Li, Z.; Wang, Y.; Fang, Z.; et al. Fine mapping and candidate gene identification of the genic male-sterile gene ms3 in cabbage 51S. Theor. Appl. Genet. 2018, 131, 2651-2661. [CrossRef]

61. Han, F.; Zhang, X.; Yuan, K.; Fang, Z.; Yang, L.; Zhuang, M.; Zhang, Y.; Wang, Y.; Liu, Y.; Li, Z.; et al. A user-friendly KASP molecular marker developed for the DGMS-based breeding system in Brassica oleracea species. Mol. Breed. 2019, 39, 90. [CrossRef]

62. Ogura, H. Studies on the new male sterility in Japanese radish, with special references on the utilization of this sterility towards the practical raising of hybrid seeds. Mem. Fac. Agric. Kagoshima Univ. 1968, 6, 40-75.

63. Uyttewaal, M.; Arnal, N.; Quadrado, M.; Martin-Canadell, A.; Vrielynck, N.; Hiard, S.; Gherbi, H.; Bendahmane, A.; Budar, F.; Mireau, H. Characterization of Raphanus sativus Pentatricopeptide Repeat Proteins Encoded by the Fertility Restorer Locus for Ogura Cytoplasmic Male Sterility. Plant Cell 2009, 20, 3331-3345. [CrossRef]

64. Yamagishi, H.; Jikuya, M.; Okushiro, K.; Hashimoto, A.; Fukunaga, A.; Takenaka, M.; Terachi, T. A single nucleotide substitution in the coding region of Ogura male sterile gene, orf138, determines effectiveness of a fertility restorer gene, Rfo, in radish. Mol. Genet. Genom. 2021, 296, 705-717. [CrossRef]

65. Bannerot, H.; Boulidard, L.; Cauderon, Y.; Tempe, J. Transfer of cytoplasmic male sterility from Raphanus sativus to Brassica oleracea. Proc. Eucarpia Meet. Crucif. 1974, 25, 52-54.

66. Sigareva, M.A.; Earle, E.D. Direct transfer of a cold-tolerant Ogura male-sterile cytoplasm into cabbage (Brassica oleracea ssp. capitata) via protoplast fusion. Theor. Appl. Genet. 1997, 94, 213-220. [CrossRef]

67. Shu, J.; Liu, Y.; Li, Z.; Zhang, L.; Fang, Z.; Yang, L.; Zhuang, M.; Zhang, Y.; Lv, H. Detection of the Diversity of Cytoplasmic Male Sterility Sources in Broccoli (Brassica oleracea var. Italica) Using Mitochondrial Markers. Front. Plant Sci. 2016, 7, 927. [CrossRef] [PubMed]

68. Wang, Q.; Zhang, Y.; Fang, Z.; Liu, Y.; Yang, L.; Zhuang, M. Chloroplast and mitochondrial SSR help to distinguish allo-cytoplasmic male sterile types in cabbage (Brassica oleracea L. var. capitata). Mol. Breed. 2011, 30, 709-716. [CrossRef]

69. Yao, X.; Li, Y.; Xie, Z.; Liu, L. Identification of specific SRAP marker associated with cytoplasmic male sterility gene of broccoli. Mol. Plant Breed. 2009, 7, 941-947.

70. Sampson, D.R. Linkage of genetic male sterility with a seedling marker and its use in producing f1 hybrid seed of brassica oleracea (cabbage, broccoli, kale, etc.). Can. J. Plant Sci. 1966, 46, 703. [CrossRef]

71. Ruffio-Chable, V.; Bellis, H.; Herve, Y. A dominant gene for male sterility in cauliflower (Brassica oleracea var. botrytis): Phenotype expression, inheritance, and use in F1 hybrid production. Euphytica 1993, 67, 9-17. [CrossRef]

72. Fang, Z.; Sun, P.; Liu, Y.; Yang, L.; Wang, X.; Hou, A.; Bian, C. A male sterile line with dominant gene (Ms) in cabbage (Brassica oleracea var. capitata) and its utilization for hybrid seed production. Euphytica 1997, 97, 265-268. [CrossRef]

73. Ji, J.-L.; Yang, L.-M.; Fang, Z.-Y.; Zhuang, M.; Zhang, Y.-Y.; Lv, H.-H.; Liu, Y.-M.; Li, Z.-S. Recessive male sterility in cabbage (Brassica oleracea var. capitata) caused by loss of function of BoCYP704B1 due to the insertion of a LTR-retrotransposon. Theor. Appl. Genet. 2017, 130, 1441-1451. [CrossRef] [PubMed]

74. Shu, J.; Liu, Y.; Li, Z.; Zhang, L.; Fang, Z.; Yang, L.; Zhuang, M.; Lv, H. A generic SSR marker closely linked to a dominant genic male sterility gene (DGMs79-399-3) in broccoli (Brassica oleracea var. italica). Mol. Breed. 2016, 36, 86. [CrossRef]

75. Yu, H.-L.; Fang, Z.-Y.; Liu, Y.-M.; Yang, L.-M.; Zhuang, M.; Lv, H.; Li, Z.-S.; Han, F.-Q.; Liu, X.-P.; Zhang, Y.-Y. Development of a novel allele-specific Rfo marker and creation of Ogura CMS fertility-restored interspecific hybrids in Brassica oleracea. Theor. Appl. Genet. 2016, 129, 1625-1637. [CrossRef] [PubMed]

76. Liu, C.-Q.; Li, G.-Q.; Yao, X.-Q.; Huang, L.; Wu, X.-Y.; Xie, Z.-J. Characterization of Ogura CMS fertility-restored interspecific hybrids and backcross progenies from crosses between broccoli and rapeseed. Euphytica 2020, 216, 1-12. [CrossRef]

77. Monot, C.; Pajot, E.; Le Corre, D.; Silué, D. Induction of systemic resistance in broccoli (Brassica oleracea var. botrytis) against downy mildew (Peronospora parasitica) by avirulent isolates. Biol. Control. 2002, 24, 75-81. [CrossRef]

78. Monot, C.; Penguilly, D.; Silué, D. First confirmed report of downy mildew caused by Hyaloperonospora parasitica on broccoli, cauliflower and Romanesco-type cauliflower heads in France. Plant Pathol. 2010, 59, 1165. [CrossRef]

79. Farinhó, M.; Coelho, P.; Carlier, J.; Svetleva, D.; Monteiro, A.; Leitão, J.M. Mapping of a locus for adult plant resistance to downy mildew in broccoli (Brassica oleracea convar. italica). Theor. Appl. Genet. 2004, 109, 1392-1398. [CrossRef]

80. Wang, M.; Farnham, M.W.; Thomas, C.E. Phenotypic Variation for Downy Mildew Resistance among Inbred Broccoli. HortScience 2000, 35, 925-929. [CrossRef]

81. Wang, M.; Farnham, M.W.; Thomas, C.E. Inheritance of True Leaf Stage Downy Mildew Resistance in Broccoli. J. Am. Soc. Hortic. Sci. 2001, 126, 727-729. [CrossRef]

82. Giovannelli, J.L.; Farnham, M.W.; Wang, M.; Strand, A.E. Development of Sequence Characterized Amplified Region Markers Linked to Downy Mildew Resistance in Broccoli. J. Am. Soc. Hortic. Sci. 2002, 127, 597-601. [CrossRef]

83. Farnham, M.; Wang, M.; Thomas, C. A single dominant gene for downy mildew resistance in broccoli. Euphytica 2002, 128, 405-407. [CrossRef]

84. Coelho, P.S.; Monteiro, A.A. Inheritance of downy mildew resistance in mature broccoli plants. Euphytica 2003, 131, 65-69. [CrossRef] 
85. Belser, C.; Istace, B.; Denis, E.; Dubarry, M.; Baurens, F.-C.; Falentin, C.; Genete, M.; Berrabah, W.; Chèvre, A.-M.; Delourme, R.; et al. Chromosome-scale assemblies of plant genomes using nanopore long reads and optical maps. Nat. Plants 2018, 4, 879-887. [CrossRef] [PubMed]

86. Lovelock, D.A.; Donald, C.E.; Conlan, X.; Cahill, D.M. Salicylic acid suppression of clubroot in broccoli (Brassicae oleracea var. italica) caused by the obligate biotroph Plasmodiophora brassicae. Australas. Plant Pathol. 2012, 42, 141-153. [CrossRef]

87. Crute, I.; Gray, A.; Crisp, P.; Buczacki, S. Variation in Plasmodiophora brassicae and resistance to clubroot disease in brassicas and allied crops-a critical review. Plant Breed. Abstr. 1980, 50, 91-104.

88. Hirai, M. Genetic Analysis of Clubroot Resistance in Brassica Crops. Breed. Sci. 2006, 56, 223-229. [CrossRef]

89. Voorrips, R.E. Plasmodiophora brassicae: Aspects of pathogenesis and resistance in Brassica oleracea. Euphytica 1995, 83, 139-146. [CrossRef]

90. Diederichsen, E.; Frauen, M.; Linders, E.G.A.; Hatakeyama, K.; Hirai, M. Status and Perspectives of Clubroot Resistance Breeding in Crucifer Crops. J. Plant Growth Regul. 2009, 28, 265-281. [CrossRef]

91. Hirani, A.; Gao, F.; Liu, J.; Fu, G.; Wu, C.; McVetty, P.B.E.; Duncan, R.W.; Li, G. Combinations of Independent Dominant Loci Conferring Clubroot Resistance in All Four Turnip Accessions (Brassica rapa) from the European Clubroot Differential Set. Front. Plant Sci. 2018, 9, 1628. [CrossRef]

92. Gan, C.; Deng, X.; Cui, L.; Yu, X.; Yuan, W.; Dai, Z.; Yao, M.; Pang, W.; Ma, Y.; Yu, X.; et al. Construction of a high-density genetic linkage map and identification of quantitative trait loci associated with clubroot resistance in radish (Raphanus sativus L.). Mol. Breed. 2019, 39, 1-12. [CrossRef]

93. Li, L.; Luo, Y.; Chen, B.; Xu, K.; Zhang, F.; Li, H.; Huang, Q.; Xiao, X.; Zhang, T.; Hu, J.; et al. A Genome-Wide Association Study Reveals New Loci for Resistance to Clubroot Disease in Brassica napus. Front. Plant Sci. 2016, 7, 1483. [CrossRef]

94. Ren, W.; Li, Z.; Han, F.; Zhang, B.; Li, X.; Fang, Z.; Yang, L.; Zhuang, M.; Lv, H.; Liu, Y.; et al. Utilization of Ogura CMS germplasm with the clubroot resistance gene by fertility restoration and cytoplasm replacement in Brassica oleracea L. Hortic. Res. 2020, 7, 1-10. [CrossRef] [PubMed]

95. Rocherieux, J.; Glory, P.; Giboulot, A.; Boury, S.; Barbeyron, G.; Thomas, G.; Manzanares-Dauleux, M.J. Isolate-specific and broad-spectrum QTLs are involved in the control of clubroot in Brassica oleracea. Theor. Appl. Genet. 2004, 108, 1555-1563. [CrossRef]

96. Nagaoka, T.; Doullah, M.A.U.; Matsumoto, S.; Kawasaki, S.; Ishikawa, T.; Hori, H.; Okazaki, K. Identification of QTLs that control clubroot resistance in Brassica oleracea and comparative analysis of clubroot resistance genes between B. rapa and B. oleracea. Theor. Appl. Genet. 2010, 120, 1335-1346. [CrossRef]

97. Peng, L.; Zhou, L.; Li, Q.; Wei, D.; Ren, X.; Song, H.; Mei, J.; Si, J.; Qian, W. Identification of Quantitative Trait Loci for Clubroot Resistance in Brassica oleracea With the Use of Brassica SNP Microarray. Front. Plant Sci. 2018, 9, 822. [CrossRef]

98. Mirik, M.; Selcuk, F.; Aysan, Y.; Sahin, F. First Outbreak of Bacterial Black Rot on Cabbage, Broccoli, and Brussels Sprouts Caused by Xanthomonas campestris pv. campestris in the Mediterranean Region of Turkey. Plant Dis. 2008, 92, 176. [CrossRef] [PubMed]

99. Nagai, H.; Miyake, N.; Kato, S.; Maekawa, D.; Inoue, Y.; Takikawa, Y. Improved control of black rot of broccoli caused by Xanthomonas campestris pv. campestris using a bacteriophage and a nonpathogenic Xanthomonas sp. strain. J. Gen. Plant Pathol. 2017, 83, 373-381. [CrossRef]

100. Sakai, H.; Ikeda, K.; Urushibara, T.; Shiraishi, T. Black rot of broccoli (Brassica oleracea var. italica) caused by Xanthomonas campestris pv. campestris. Jpn. J. Phytopathol. 2006, 72, 116-119. [CrossRef]

101. Saha, P.; Kalia, P.; Sharma, M.; Singh, D. New source of black rot disease resistance in Brassica oleracea and genetic analysis of resistance. Euphytica 2016, 207, 35-48. [CrossRef]

102. Afrin, K.S.; Rahim, A.; Park, J.-I.; Natarajan, S.; Kim, H.-T.; Nou, I.-S. Identification of NBS-encoding genes linked to black rot resistance in cabbage (Brassica oleracea var. capitata). Mol. Biol. Rep. 2018, 45, 773-785. [CrossRef]

103. Afrin, K.S.; Rahim, A.; Park, J.-I.; Natarajan, S.; Rubel, M.H.; Kim, H.-T.; Nou, A.I.-S. Screening of Cabbage (Brassica oleracea L.) Germplasm for Resistance to Black Rot. Plant Breed. Biotechnol. 2018, 6, 30-43. [CrossRef]

104. Doullah, M.; Mohsin, G.; Ishikawa, K.; Hori, H.; Okazaki, K. Construction of a Linkage Map and QTL analysis for Black Rot Resistance in Brassica oleracea L. Int. J. Nat. Sci. 2011, 1, 1-6. [CrossRef]

105. Tonu, N.N.; Doullah, A.-U.; Shimizu, M.; Karim, M.; Kawanabe, T.; Fujimoto, R.; Okazaki, K. Comparison of Positions of QTLs Conferring Resistance to Xanthomonas campestris pv. campestris in Brassica oleracea. Am. J. Plant Sci. 2013, 4, 11-20. [CrossRef]

106. Lee, Y.H.; Hong, J.K. Differential defence responses of susceptible and resistant kimchi cabbage cultivars to anthracnose, black spot and black rot diseases. Plant Pathol. 2014, 64, 406-415. [CrossRef]

107. Iglesias-Bernabé, L.; Madloo, P.; Rodríguez, V.M.; Francisco, M.; Soengas, P. Dissecting quantitative resistance to Xanthomonas campestris pv. campestris in leaves of Brassica oleracea by QTL analysis. Sci. Rep. 2019, 9, 2015. [CrossRef] [PubMed]

108. Frerigmann, H.; Gigolashvili, T. MYB34, MYB51, and MYB122 Distinctly Regulate Indolic Glucosinolate Biosynthesis in Arabidopsis thaliana. Mol. Plant 2014, 7, 814-828. [CrossRef] [PubMed]

109. Guo, L.; Yang, R.; Gu, Z. Cloning of genes related to aliphatic glucosinolate metabolism and the mechanism of sulforaphane accumulation in broccoli sprouts under jasmonic acid treatment. J. Sci. Food Agric. 2016, 96, 4329-4336. [CrossRef]

110. Li, G.; Riaz, A.; Goyal, S.; Abel, S.; Quiros, C. Inheritance of Three Major Genes Involved in the Synthesis of Aliphatic Glucosinolates in Brassica oleracea. J. Am. Soc. Hortic. Sci. 2001, 126, 427-431. [CrossRef] 
111. Traka, M.H.; Saha, S.; Huseby, S.; Kopriva, S.; Walley, P.G.; Barker, G.C.; Moore, J.; Mero, G.; van den Bosch, F.; Constant, H.; et al. Genetic regulation of glucoraphanin accumulation in Beneforte ${ }^{\circledR}$ broccoli. New Phytol. 2013, 198, 1085-1095. [CrossRef] [PubMed]

112. Xu, R.; Kong, W.W.; Peng, Y.F.; Zhang, K.X.; Li, R.; Li, J. Identification and expression pattern analysis of the glucosinolate biosynthetic gene BoCYP83B1 from broccoli. Biol. Plant. 2018, 62, 521-533. [CrossRef]

113. Yu, Q.; Hao, G.; Zhou, J.; Wang, J.; Evivie, E.R.; Li, J. Identification and expression pattern analysis of BoMYB51 involved in indolic glucosinolate biosynthesis from broccoli (Brassica oleracea var. italica). Biochem. Biophys. Res. Commun. 2018, 501, 598-604. [CrossRef] [PubMed]

114. Rahim, A.; Afrin, K.S.; Jung, H.-J.; Kim, H.-T.; Park, J.-I.; Hur, Y.; Nou, I.S. Molecular analysis of anthocyanin biosynthesis-related genes reveal BoTT8 associated with purple hypocotyl of broccoli (Brassica oleracea var. italica L.). Genome 2019, 62, 253-266. [CrossRef] [PubMed]

115. Sotelo, T.; Soengas, P.; Velasco, P.; Rodríguez, V.M.; Cartea, M.E. Identification of Metabolic QTLs and Candidate Genes for Glucosinolate Synthesis in Brassica oleracea Leaves, Seeds and Flower Buds. PLoS ONE 2014, 9, e91428. [CrossRef]

116. Brown, A.F.; Yousef, G.G.; Reid, R.W.; Chebrolu, K.K.; Thomas, A.; Krueger, C.; Jeffery, E.; Jackson, E.; Juvik, J.A. Genetic analysis of glucosinolate variability in broccoli florets using genome-anchored single nucleotide polymorphisms. Theor. Appl. Genet. 2015, 128, 1431-1447. [CrossRef]

117. Li, Z.; Liu, Y.; Yuan, S.; Han, F.; Fang, Z.; Yang, L.; Zhuang, M.; Zhang, Y.; Lv, H.; Wang, Y.; et al. Fine mapping of the major QTLs for biochemical variation of sulforaphane in broccoli florets using a DH population. Sci. Rep. 2021, 11, 9004. [CrossRef]

118. Brown, A.F.; Yousef, G.G.; Chebrolu, K.K.; Byrd, R.W.; Everhart, K.W.; Thomas, A.; Reid, R.; Parkin, I.A.P.; Sharpe, A.G.; Oliver, R.; et al. High-density single nucleotide polymorphism (SNP) array mapping in Brassica oleracea: Identification of QTL associated with carotenoid variation in broccoli florets. Theor. Appl. Genet. 2014, 127, 2051-2064. [CrossRef]

119. Gardner, A.M.; Brown, A.F.; Juvik, J.A. QTL analysis for the identification of candidate genes controlling phenolic compound accumulation in broccoli (Brassica oleracea L. var. italica). Mol. Breed. 2016, 36, 81. [CrossRef]

120. Francisco, M.; Ali, M.A.A.; Ferreres, F.; Moreno-Fernández, D.; Ángel; Velasco, P.; Soengas, P. Organ-Specific Quantitative Genetics and Candidate Genes of Phenylpropanoid Metabolism in Brassica oleracea. Front. Plant Sci. 2016, 6, 1240. [CrossRef]

121. Gao, J.; Yu, X.; Ma, F.; Li, J. RNA-Seq Analysis of Transcriptome and Glucosinolate Metabolism in Seeds and Sprouts of Broccoli (Brassica oleracea var. italic). PLoS ONE 2014, 9, e88804. [CrossRef]

122. Lee, Y.-S.; Ku, K.-M.; Becker, T.M.; Juvik, J.A. Chemopreventive glucosinolate accumulation in various broccoli and collard tissues: Microfluidic-based targeted transcriptomics for by-product valorization. PLoS ONE 2017, 12, e0185112. [CrossRef]

123. Li, Z.; Liu, Y.; Li, L.; Fang, Z.; Yang, L.; Zhuang, M.; Zhang, Y.; Lv, H. Transcriptome reveals the gene expression patterns of sulforaphane metabolism in broccoli florets. PLoS ONE 2019, 14, e0213902. [CrossRef]

124. Parkin, I.A.P.; Koh, C.; Tang, H.; Robinson, S.J.; Kagale, S.; Clarke, W.E.; Town, C.D.; Nixon, J.; Krishnakumar, V.; Bidwell, S.L.; et al. Transcriptome and methylome profiling reveals relics of genome dominance in the mesopolyploid Brassica oleracea. Genome Biol. 2014, 15, R77. [CrossRef]

125. Liu, S.; Liu, Y.; Yang, X.; Tong, C.; Edwards, D.; Parkin, I.A.P.; Zhao, M.; Perumal, S.; Yu, J.; Huang, S.; et al. The Brassica oleracea genome reveals the asymmetrical evolution of polyploid genomes. Nat. Commun. 2014, 5, 3930. [CrossRef] [PubMed]

126. Shen, Y.; Wang, J.; Shaw, R.K.; Yu, H.; Sheng, X.; Zhao, Z.; Li, S.; Gu, H. Development of GBTS and KASP Panels for Genetic Diversity, Population Structure, and Fingerprinting of a Large Collection of Broccoli (Brassica oleracea L. var. italica) in China. Front. Plant Sci. 2021, 12, 655254. [CrossRef] [PubMed]

127. Huang, J.; Liu, Y.; Han, F.; Fang, Z.; Yang, L.; Zhuang, M.; Zhang, Y.; Lv, H.; Wang, Y.; Jialei, J.; et al. Genetic Diversity and Population Structure Analysis of 161 Broccoli Cultivars Based on SNP Markers. Hortic. Plant J. 2021. [CrossRef]

128. Silva, G.; Poirot, L.; Galetto, R.; Smith, J.; Montoya, G.; Duchateau, P.; Paques, F. Meganucleases and Other Tools for Targeted Genome Engineering: Perspectives and Challenges for Gene Therapy. Curr. Gene Ther. 2011, 11, 11-27. [CrossRef]

129. Kim, Y.G.; Cha, J.; Chandrasegaran, S. Hybrid restriction enzymes: Zinc finger fusions to Fok I cleavage domain. Proc. Natl. Acad. Sci. USA 1996, 93, 1156. [CrossRef]

130. Christian, M.; Cermak, T.; Doyle, E.L.; Schmidt, C.; Zhang, F.; Hummel, A.; Bogdanove, A.J.; Voytas, D.F. Targeting DNA Double-Strand Breaks with TAL Effector Nucleases. Genetics 2010, 186, 757-761. [CrossRef]

131. Mali, P.; Esvelt, K.M.; Church, G. Cas9 as a versatile tool for engineering biology. Nat. Methods 2013, 10, 957-963. [CrossRef] [PubMed]

132. Ma, X.; Zhang, X.; Liu, H.; Li, Z. Highly efficient DNA-free plant genome editing using virally delivered CRISPR-Cas9. Nat. Plants 2020, 6, 773-779. [CrossRef] [PubMed]

133. Liu, X.; Wu, S.; Xu, J.; Sui, C.; Wei, J. Application of CRISPR/Cas9 in plant biology. Acta Pharm. Sin. B 2017, 7, 292-302. [CrossRef] [PubMed]

134. Ma, C.; Zhu, C.; Zheng, M.; Liu, M.; Zhang, D.; Liu, B.; Li, Q.; Si, J.; Ren, X.; Song, H. CRISPR/Cas9-mediated multiple gene editing in Brassica oleracea var. capitata using the endogenous tRNA-processing system. Hortic. Res. 2019, 6, 20. [CrossRef]

135. Sun, B.; Jiang, M.; Zheng, H.; Jian, Y.; Huang, W.-L.; Yuan, Q.; Zheng, A.-H.; Chen, Q.; Zhang, Y.-T.; Lin, Y.-X.; et al. Color-related chlorophyll and carotenoid concentrations of Chinese kale can be altered through CRISPR/Cas 9 targeted editing of the carotenoid isomerase gene BoaCRTISO. Hortic. Res. 2020, 7, 161. [CrossRef] [PubMed]

136. Lawrenson, T.; Shorinola, O.; Stacey, N.; Li, C.; Østergaard, L.; Patron, N.; Uauy, C.; Harwood, W. Induction of targeted, heritable mutations in barley and Brassica oleracea using RNA-guided Cas9 nuclease. Genome Biol. 2015, 16, 258. [CrossRef] 
137. Sparrow, P.A.C.H.N.; Irwin, J.A. Brassica oleracea and B. napus. In Methods in Molecular Biology; Springer: Berlin/Heidelberg, Germany, 2014; Volume 1223, pp. 287-297.

138. Metz, T.D.; Dixit, R.; Earle, E.D. Agrobacterium tumefaciens-mediated transformation of broccoli (Brassica oleracea var. italica) and cabbage (B. oleracea var. capitata). Plant Cell Rep. 1995, 15, 287-292. [CrossRef]

139. Jiang, M.; Jiang, J.; He, C.; Guan, M. Broccoli plants over-expressing a cytosolic ascorbate peroxidase gene increase resistance to downy mildew and heat stress. J. Plant Pathol. 2016, 98, 413-420.

140. Jiang, M.; Liu, Q.-E.; Liu, Z.-N.; Li, J.-Z.; He, C.-M. Over-expression of a WRKY transcription factor gene BoWRKY6 enhances resistance to downy mildew in transgenic broccoli plants. Australas. Plant Pathol. 2016, 45, 327-334. [CrossRef]

141. Li, S.; Zhang, L.; Wang, Y.; Xu, F.; Liu, M.; Lin, P.; Ren, S.; Ma, R.; Guo, Y.-D. Knockdown of a cellulose synthase gene BoiCesA affects the leaf anatomy, cellulose content and salt tolerance in broccoli. Sci. Rep. 2017, 7, 41397. [CrossRef]

142. Jiang, M.; Jiang, J.-J.; Miao, L.-X.; He, C.-M. Over-expression of a C3H-type zinc finger gene contributes to salt stress tolerance in transgenic broccoli plants. Plant Cell Tissue Organ Cult. (PCTOC) 2017, 130, 239-254. [CrossRef]

143. Jiang, M.; Miao, L.; Zhang, H.; Zhu, X. Over-Expression of a Transcription Factor Gene BoC3H4 Enhances Salt Stress Tolerance but Reduces Sclerotinia Stem Rot Disease Resistance in Broccoli. J. Plant Growth Regul. 2019, 39, 1162-1176. [CrossRef]

144. Jiang, M.; Ye, Z.-H.; Zhang, H.-J.; Miao, L.-X. Broccoli Plants Over-expressing an ERF Transcription Factor Gene BoERF1 Facilitates Both Salt Stress and Sclerotinia Stem Rot Resistance. J. Plant Growth Regul. 2018, 38, 1-13. [CrossRef]

145. Kumar, P.; Gambhir, G.; Gaur, A.; Sharma, K.C.; Thakur, A.K.; Srivastava, D.K. Development of transgenic broccoli with cryIAa gene for resistance against diamondback moth (Plutella xylostella). 3 Biotech 2018, 8, 299. [CrossRef]

146. Zuluaga, D.L.; Graham, N.S.; Klinder, A.; Kloeke, A.E.E.V.O.; Marcotrigiano, A.R.; Wagstaff, C.; Verkerk, R.; Sonnante, G.; Aarts, M.G.M. Overexpression of the MYB29 transcription factor affects aliphatic glucosinolate synthesis in Brassica oleracea. Plant Mol. Biol. 2019, 101, 65-79. [CrossRef] [PubMed]

147. Li, R.; Jiang, J.; Jia, S.; Zhu, X.; Su, H.; Li, J. Overexpressing broccoli tryptophan biosynthetic genes BoTSB1 and BoTSB2 promotes biosynthesis of IAA and indole glucosinolates. Physiol. Plant. 2019, 168, 174-187. [CrossRef]

148. Kim, Y.-C.; Cha, A.; Hussain, M.; Lee, K.; Lee, S. Impact of Agrobacterium-infiltration and transient overexpression of BroMYB28 on glucoraphanin biosynthesis in broccoli leaves. Plant Biotechnol. Rep. 2020, 14, 373-380. [CrossRef]

149. Cao, H.; Liu, R.; Zhang, J.; Liu, Z.; Fan, S.; Yang, G.; Jin, Z.; Pei, Y. Improving sulforaphane content in transgenic broccoli plants by overexpressing MAM1, FMOGS-OX2, and Myrosinase. Plant Cell Tissue Organ Cult. (PCTOC) 2021, 146, 461-471. [CrossRef]

150. Chen, G.J.; Cao, B.H.; Xu, F.; Lei, J.J. Development of adjustable male sterile plant in broccoli by antisense DAD1 fragment transformation. Afr. J. Biotechnol. 2010, 9, 4534-4541.

151. Li, H.; Zhang, Q.L.; Li, L.H.; Yuan, J.Y.; Wang, Y.; Wu, M.; Han, Z.P.; Liu, M.; Chen, C.B.; Song, W.Q.; et al. Ectopic overexpression of bol-mir171b increases chlorophyll content and results in sterility in broccoli (Brassica oleracea L. var. italica). J. Agric. Food Chem. 2018, 66, 9588-9597. [CrossRef] [PubMed]

152. Baskar, V.; Park, S.W. Molecular characterization of BrMYB28 and BrMYB29 paralogous transcription factors involved in the regulation of aliphatic glucosinolate profiles in Brassica rapa ssp. pekinensis. Comptes Rendus Biol. 2015, 338, 434-442. [CrossRef] [PubMed] 